Portland State University

PDXScholar

7-26-1968

\title{
Classes and Class Conflicts in Victorian England as Explored by Thomas Hardy
}

Nancy Burns Vail

Portland State University

Follow this and additional works at: https://pdxscholar.library.pdx.edu/open_access_etds

Part of the History Commons

Let us know how access to this document benefits you.

Recommended Citation

Vail, Nancy Burns, "Classes and Class Conflicts in Victorian England as Explored by Thomas Hardy" (1968). Dissertations and Theses. Paper 746.

https://doi.org/10.15760/etd.746

This Thesis is brought to you for free and open access. It has been accepted for inclusion in Dissertations and Theses by an authorized administrator of PDXScholar. Please contact us if we can make this document more accessible: pdxscholar@pdx.edu. 
AN ABSTRACT OP THE THESIS OF Nancy Burns Vall for the Master of Sclence in Teaching presented July 26, 1968.

Title; Clasese and Clase Conflicts In Vletorien England as Exploxed by Thowne Herdy.

APPROVED BY MEMBERS OF THE THES IS COMMTTRER:

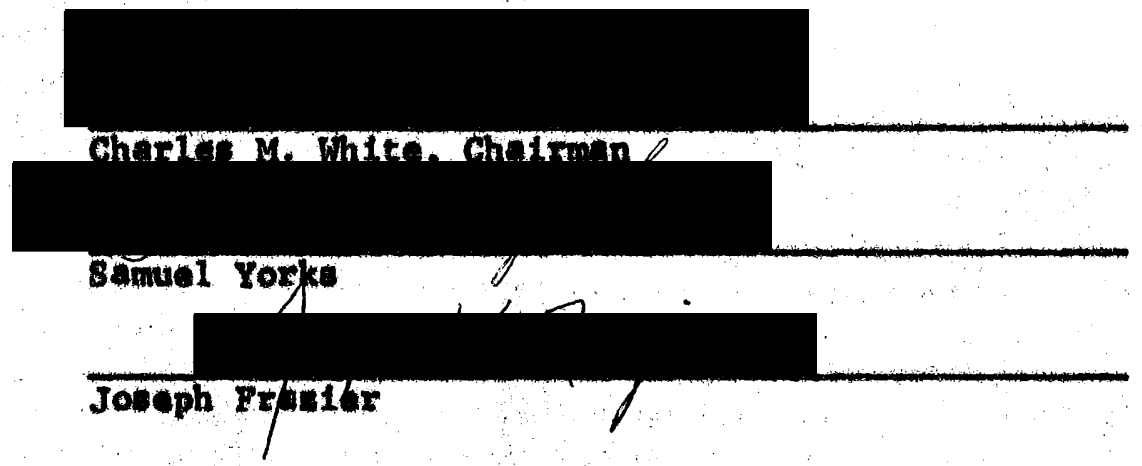

The purpose of this reveureh wat to study in dopth the relationchips of Individual in the three soclal clesses in England during the Victorian Age. Since original documente and research muterial were scarce I used two novele by Thomas Hardy to illuetrate the conflicte between representatives of the cocial b1avees. In 1891 England was proeperou and miny people belleved there was no conflict between the clesees. Thomas Haxdy belleved this was untrue and, by method of comparison, wrote rese of the d'Urbervilies and Jude the obseure to prove h1s point. This thesis includes research on the two novele, Thomas Herdy" life, and last but not leat is atudy of the Age of Victoria. 
CLASSES AND CLASS CONFLICTS IN VICTORIAN ENGLAND AS EXPLORED BY THOMAS HARDY

\author{
by \\ Nanoy Burns Vall
}

A thesis submitted in partial fulfiliment of the requirements for the degree of

\title{
MASTER OF SCIDNCE \\ IN \\ TEACHTING
}

\author{
Portland state College \\ 1968
}

PORTLAND STATE COLLEgE

LIBRARY 
TO THE OFETCE OF GRADUATE STUDIES:

The mombers of the Committee approve the thesis of

Naney Burns Vall prosented July 26, 1968.
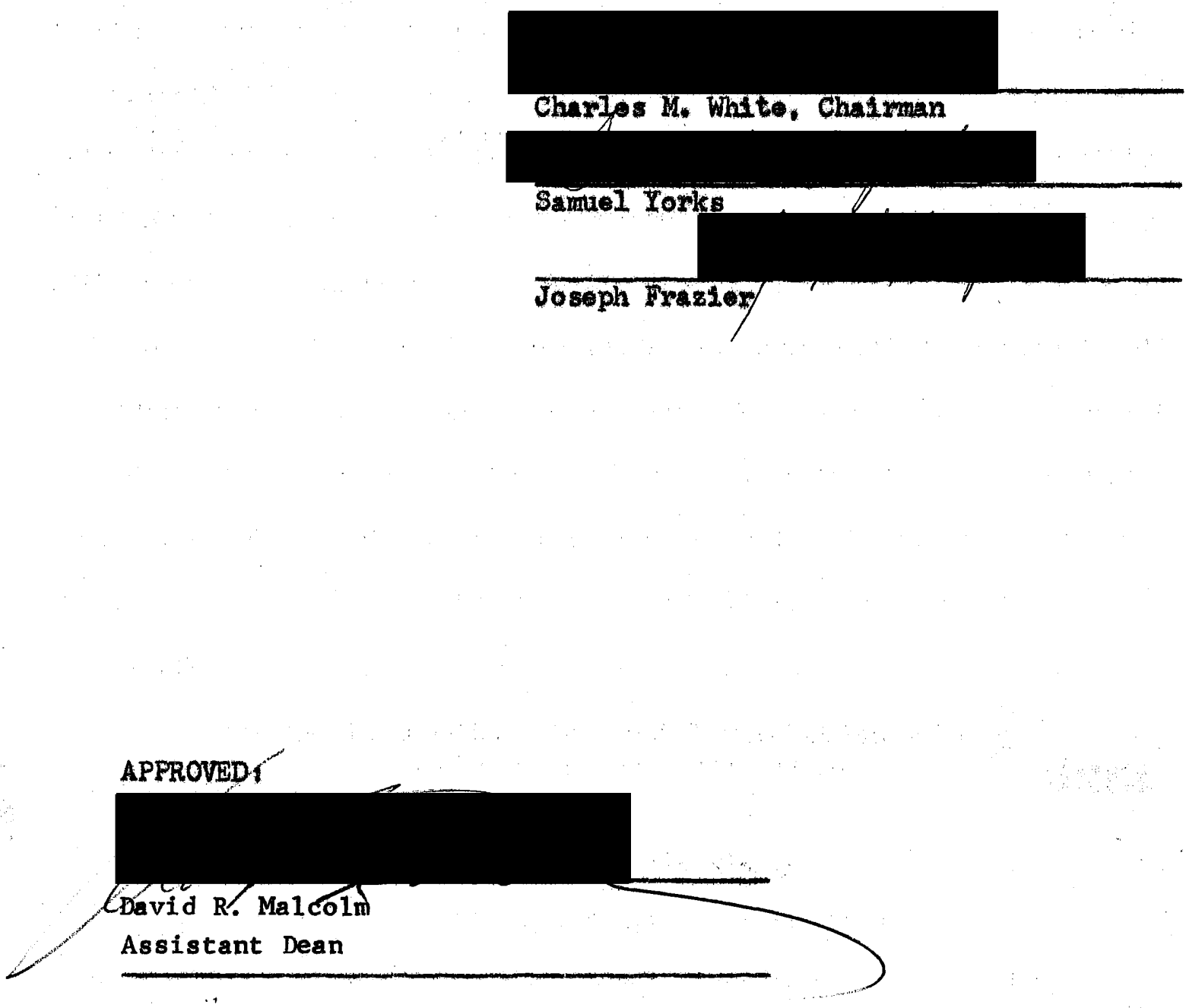

Ju1y 30, 1968

date 
Hietory has many definitions. One very genomal and all Inelusive definition is that history 1s the story of man as he interact: with other mon and with his environment. One man's life is mede ap of bundreds of ovent: large and amall. Not overy oceurrence is worthy of note. What a man eats for dinner my not be as important as what ho thought about a recent political election. Whon man roconds the ovents in his ife ho selects which faets are worth remenbering and discards the rest.

The task of seleotivity faces ang historian when he attempts to tell the stery of one natlon, ono people, we exa. The historian mat also mike a cheice and dectde which ovents and facts aro notoworthy and which on afford to be onltted. If the historian did not soreen the material he works with, he would find his dutios an inposatbility. In addition to seleating oertain facts and data to bo rocorded, an historian is recod with the job of doolding which aspect of his subjoct matter w111 be coneontrated upon. The story of a nation on be told from a mosiber atisen's polnt of viow. from a forelgnor's point of view, from a contemporary nows roporter's point of view, ote. In cach instance the tale will be different. The story of a mation or a pople ean be told with emphasis on differont aspects of soelety and oulture. The artiatic elemont of sootety may be dwelt upon, sotentifle discoveries mey bo concentrated upen. great mon of the nation may be discussod, and so forth.

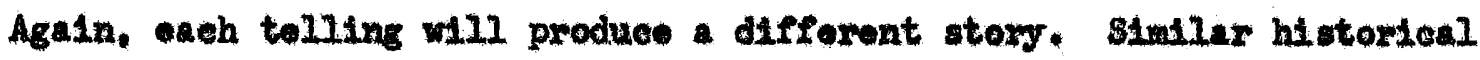
data will reappear throughout eqeh inotanee but esgentialiy the histories will be unalike. 
Eecause histowians must make a cholec and declde which netion they will write an history of, which poole in the world are historieally algnifleant, which contury or ora in a nation or people's history is important. recorders of history mut juatify thol, choless. If a cortain aspect of on natton's history is oonatdered worthy of record, thon there mast be reason. Many of these mesons will bo porsonal bocause histordans ar Ikke other men. Inolinations towards the arts or setences, military or teohnteal inMuenes thol deelstons just as they do nonhistortans.

As an historian. I have a partioular interest in the history of Grout Britain. In the history of the world she has been a leador and the bodrook of institutions of government and the arts and solenees which have continued in an ubbokon trudition througheat the history of mankind. Although nany perieds of hor history are Interesting as well as Ignifieant, the ninoteenth contury In England's history-the ora knom as the Viotorien Age-is to the entury whoh is the most fasolnating. In thil one poriod is a walth of information full of his-

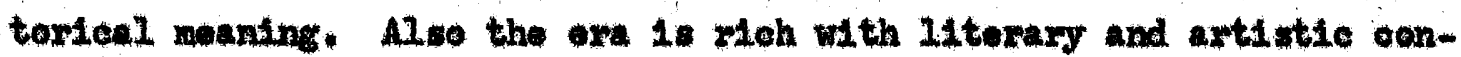
tributions, If this wor not enough, I sec throughort the age many points where the histerked and 1 terary wovlds interiock with each other. In dosens of Instanees, Ilterary flgures are proinent in the polition ophow atch as Denjamin Diarall, an important politiolan who wrote Conting ibx in 1844 and Sybti in 1845 (11torayy landmarks) in an offort to make the public aware of exuelal sootel issues. Charlos Diahone is perhaps the most outstanding oxample of another 21terary figure who combined polithes wh literature. Ifremy novel he wroto stimalated the mading 
public to take a harah look at some suffering aspect of soolety. Many woforms wore pessed during the Vietorien peried which corrected sooial infuatices. Howover, look at the authors who wrote in the latter portion of the contury points out that not all social 111 s had boen solved. Aftor I nead soveral novels by Thome Hardy (1840-1928). I wondered why ho was extlical of a society that wes oupposed to have cured itsolf of major social Inequalities. Also, I was ourious about the faet that Bnody usod a pro-Induatrial sotting for his novis to 11liustrate the griovanoes he had againet a sootety that was doep in the middle of the machtne age. A closex look at Hardy's novelis and of the hatorical ovents of the Vietortan Age helped to meke elear the feet that Thowa Hardy was, like Diekent and Dismell before him, a soctal oritie who used his novels to enll the public's attention to a soulal injuation. 
Great Britain during the Victorlan Bra had ben going through a constant state of transition and $\mathrm{fux}$. Old traditions and values which had held true for enturtes wowe bolng undermined by new discoveries and bollefs. The very way in which pooplo on the streat interaeted with oaeh other ohanged. Old muners and oustoms wor no longer held oscred and trouted with aned respect. Bven the Chureh of England, bolwark of the

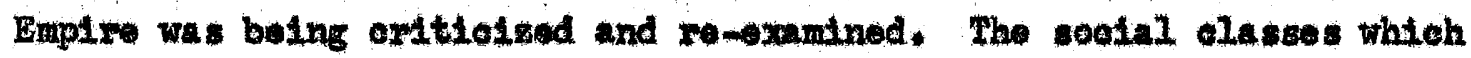
had previously establi whed themalves on the top of the soeletal ramble were no Ionger Isolated from contact with the lower and midile classes. In the days of Morrie England" the vory wollthy upper clases bad Ittlo to do with the 1owre claseos unlose it wa In a patermilstio way of if they had an employor-employe relationshap. Whth ingland in a state of solil confuston, all soctal alasses vere disoovering that the old Ines of soesal distanetion wore crumbling down about them. It wa

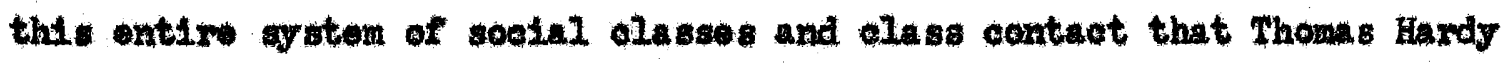
found unaceoptable In English society. He saw in the pest and ho on in the presont a pattem of social injustices comptted beouse of the sovere Ines of disturotion exteblished between soetal elases. the same situation oxdated in pe-industrial Fngland as atd in Industrial England only Haxdy folt that bis conteraponary countrymen had forgotten that sueh sootal Imblances oxdeted in modom socioty. He made his isures very clear to the reading publie by placting his characters in an agrieultural, pre-industriel sotting. the whon such social eleavages and antagonisus betweon the clasaes were expllestly obvious, A question which remalns to be ans-

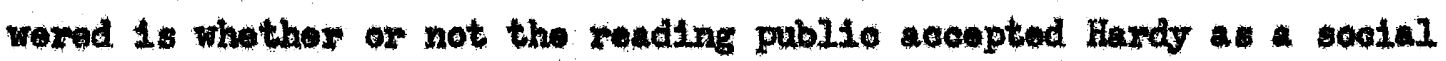




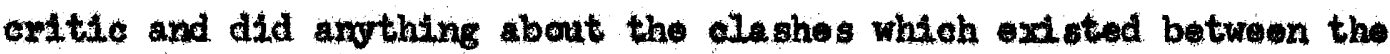
sooial olasses as a result of his novels" attaek.

The last quarter of a century during the 1800 ' was extrexuly different from the first quartor. Dat11 1832 and the Alrot great Rofom Bill. England was in overy sense of tho woxd, "Norrite England." For hundreds of years England's oconomic and soclel foundation bad been ono of agxiculture. Despite the advances made since the incoption of the Industrial Rovolution in 1760, mang pople still medo thoir living from the Iand.

Motween the years 1802 and 1832 the extating system of British farming, by whtoh land was onned by landlords, ocoupted by tenants, and cultivated by labourers, was practionlly universal, "1 This syston of agrieultural developmont was not unlike the farming practioes of Elizabothan altieons of England. It had provalied in England for conturios and had remelnod basieally unohanged oven though agriculture iteolf was gradually being industrialized.

During the Napoleonte Wars pricos for agrieultural preduot wont up consudorably due to the faot that domand inereased during wartime, The increase in prices caused agrieulturel land to be conaidered soarce and valuable combodity during the enrly years of the Vlotorlan Age. As 2 wewlt the Enolosure Novenont gatnod great momentum. 2 In less than a

1H. D. Truill and J* S. Mann, Hditors, Soolal England, Vol, VI (Landon, 1904). P. 102.

The Enolosure Movenent was an effort made to put as much axable land as posaible Into agrieultuxal produetion. 
entury more than six million acres were enclosed in onder to increase agrleultural production, 3

Landlords, tonants and labourers were all Involved in the Enelosure Movoment. Although at the turn of the ninoteonth century some industrial advaneoments were belng mad in the fleld of agrieulture, the opening of now lands to eult1vation (brought about by the Enclogure Movoment) meant that for every man who left the farn to work in the oity thero was a man needed to work newly opened Farn land. Prior to this time mush land whioh could have beon put to egrioultural use was loft opon in what was kmown as comons, of lands open to all. Ones the Enolosure Movement began, open fields wer turnod into noat roctangular farms separated by hodgos and wooden fonces, fons or mazshes wore drained and meh wast land was reelaimed, The high war-time agxicultural priees from 1815 to 1832 saw many people firaly tied to the soil. England wa still very much an agrieultural nation. Beause agrioultural pres were high due to a stimulated war-time and post-wax conony, agrleultural outpat was foreed to incroase in y1eld 4 The onelosure of comons, fons and wasteland holpod to ease the situation somewhet for mowe arable land woant more orops could be planted, therefore, more yleld and proflt for the pople involved. "Dy 1845 the Loñolonire] movenent was almost complotod; about 4,000 nots had beon passed, affoeting

3R. J. Mtoholl and M. D. R. Ioys, A Hotory of the Bnglish People (Now Tork and Londen, 1950). P. 385.

4. England could not import foreign whent to foed her population and fulfill the demand because of the exdeting Corn Laws (high tarlffis) whileh prevented forelgn whent from ontering the country. 
over 6,000,000 aeres, of a fifth of the country. The area inelosed [Sig] by agreement was apparently far larger. perhaps twice as great." England was of small geographic proportions, only a limited percentage of Iand could be pat into intensive agricultural ure. This restriotion forced agriculturists to look for tochnologieal improvements rather than to oxpect more land to bo brought under tillage. 6

G. D. H. Cole has writton, athe period of the Napoloonte Wars is remarkable not so ruoh for its great inventions LgFicultural as well as Industris] ... as for the momentum and speed of actual oconombla ohange"7 Small farmers could not expoct to sustain the impact of technology. They had neither the eapital nor the manpower to invest in order to profit. "Druing the period $1790,-1850$ the mall farmer disappeared, and the modern " system of large-sealo opptallatio farming developed."8 It took large amounts of capttal investment to support the technologieal advancenents needed in the agrieultural fleld. The old mothods of farming usod before the Inelosure Hovement was filled with defects, For example, "Under the. couren husbandy no oultivator could adopt an improvemont unioss bo could get all his nelghbors to aswont to $1 t \ldots$ mueh time and labour was lost in taking men and horses from on to another of the scattered strips. "9

5Horbert Heaton, Eeonomie Hístory of Bumope (Now York, 1948), p. 414. 6"By 1900 an open filld or comon pature was eurlosity, the land had been divided into compact farms and flelds, and the 2,000,000 aares of comnon of wasteland that romained were regarded as worthless..." 1bid.

7G. D. H. Cole and Raymond Postgate, The Bretigh Common People (London, 1961), p. 118.

8MLIton Briggs and Porey Joxdan, Economic glistony of England, Part II (London, 1949), pp. 135-136.

91bid., p. 133. 
Also, aomuon pasture land wa usually over-stoeked with enttlo, and it was diffloult to keop down diseases when all the shoep of the viliage were herded together in one flock. The Enclosure Movement served to bring together sall sections of 1solated farmand. As a realt, the standards of farming in England wer ralsed for. "Once land was onclosed the owner could take advantage of the now mothods of famang, and put the land to the most conemial use."10

The Arricultural Revolution in torms of tochnologleal advancents

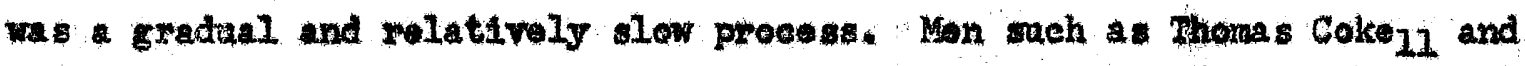
Robert Bakswell $I_{12}$ gave the movenent momentum. Cake was one of the first to adrocate onelosing open lands and gathering togother many small farms and making ua of oapltal Investmont in the agricultural ares. Bakewall doreloped new concepts in sheep rearing, which at this time wa very in-

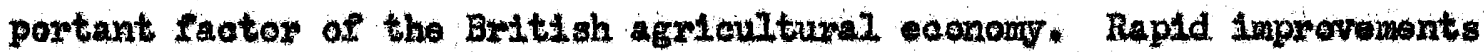
were mede in the Irvention and poxfoction of tools and machinos used in faraing. Snsll and Rotherham Improved the plough, James Nolkle of Dimbar Invented the threshing machine and the idea of a machine to spread hay to dy Lhorse tedder wo developed at this tine 13 "Probably the most general advane was the substitution of 1 ron tools for woot, and all 1ron ploughs and harrows teols for leveling plowed ground ome into use between 1830 and 1840." 14

$10_{1 \text { bid. }}$ $11(1752-1842)$

$12(1725-1795)$

13Briggs and Jordan, og. ett. p. 145 . 141bid. p. 146 . 
In order to dotornine the efroet agramentural changes had on the soctal classes in England during the arly days of the Hetoxtan Age. priees-particulariy the price of wheat-mhould bo considered. Fluctua-

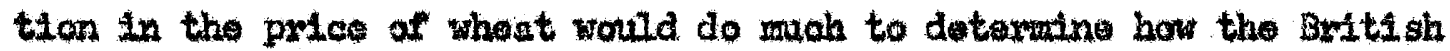
peoplo we adfusting to agrieultural developuente. the reason whet was used as a exitexton for the atandard of IIving ig oxplatnod by G. D. H. Cole! "... wheat was the comodity on which the standard of living of the comon peoplo depanded most of 11."15 since wheat, or bread, was the baste taple of the wajoxity of the people who Itved in Britain during this time, the prio of what we an indieation of how trell or how poorly the coman was Itving.

As nontioned eavilor, during tho Napoloonic War peried thro wa 2 sreat expanston in tho damand for whest. part of this demand was due to the fact that Ingland's population was steadily inowasing and part of the inereage in damand wa twe to the watemand for food to foud not only

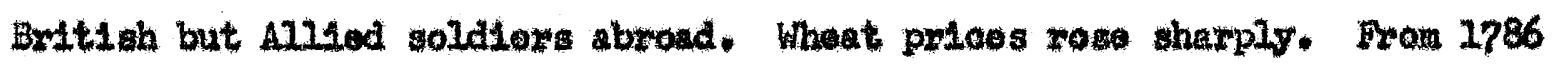
to 1825 what prloes Inoweand from 46 s. 3d. quarter. 16 to $57 \%$. 3d. a quarter. 17 The high prioe of wheat kept the cost of IIving artuflesaly high for the majority of the But1sh people. 18 the eost of basto tood comnoditleg wa evaw Inoresaing but most inowes did not increase at the sam level and dud not kep poe wth tho congtantiy cllmbing cost of wheat.

${ }^{15}$ Colo and Potgate, ag. glt., p. 120.

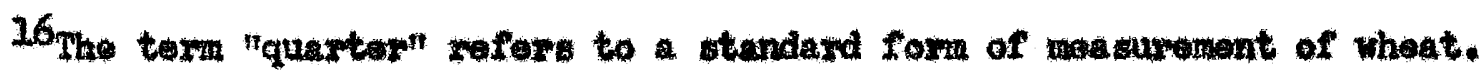

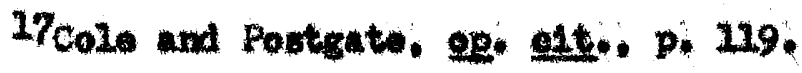
18. 1 ode. 312 
Wartime economies did not ontiroly explain the perststent high prices in wheat and similar baste food stuffs. In 1815 England suffered an agrioultural depression. The nution was plagued with bad weether and diseaso. Cattle were struck with rot, sheep were afflioted with scab, and erops such as corn were spoiled by d1sease. This stato of affairs Iasted until the fortios. "The wheat prioes from 1835 to the year of the famines $[\overline{1} 83 \overline{2}]$ showod how the oost of Ilving was artificlally hold up."19 The agrloultural depression in Bngland mant that wheat, which had beon high in domand, was oven harder to obtain on the market. The prices, therefore, contimued to be high because disease had taken a large portion of the erops whloh ordinarlly would heve been sold to the public. The remainder of the wheat orops brought inoreasingly kighor priees on the domestle market. The following is a sumary in tabular form of the pries of wheat from 1835 to 1851 . The we we the post-way years of high price and low quantity $: 20$

$\frac{70 a}{1835}$
1836
1837
1838
1839
1840
1841
1842
1843
1844
1845

\begin{tabular}{c} 
Prise of Wheat per Quartor \\
\hline 398.
\end{tabular}

(contimed on p. 11)

19 Briggs and Jordan, op. aft. p. 139 and Cole and Postgete, op. oft. p. 312 .

20

Priees are 11sted in shillings and pence. 
Yeax

1846

1847

1848

1849

1850

1851
Prices of Wheat por Quartor:

(continued)

$54 \mathrm{sh} \quad 8 \mathrm{~d}$.

69s. 9d.

50s. 6d.

44s. 3d.

40s. 3d.

38. $6 d$.

The above Information ropresents the fluctuations in the price of whert during the firteen-year post-Napoleonic War peried in British oconoulo history 21

There is one other aspect to be considered in a study of Britain's post-war agrioultural econemio ploture. Unt1l 1849 there oxisted high tariff barmers against Imported wheat. The Corn Laws or tariffs prom. vented imported whost from coming inte the country to of the agriaultural and economio exials. Such lews only added to the hardships the Brition people were suffering due to the high prices of wheat.

Bxitioh agrieulturist recovored from the post-war deprosaion and oxperienced time of economie advanes during the middle years of the mineteenth century. "Agricultaral wages Lañothor indieation of Iiving conditions had fallen abstantinlly in the forties "... By 1860 the agricultural labourers were getting on the everage rather over 20 per cont Ineresses over the wages of 1850, and by 1870 nearly 30 per cent -. by 1875 arerage wages wore about 55 por ent above the $185010 \mathrm{vel}$." Agricultural conditions hit a sover slump after a perak of great prosperity in 1870. Bad harvests plagued the farmers and between 1874 "Cole and Postgate, op. e1t. pp. 312-313. 22, 1 bid, p. 352 
and 1882 there were only two good harvests. In additlon. Reece's freez-

Ing operation was discovered in 1867 which, when later perfected, allowed forelgn whet to bo proserved and transported to England with 1ittle danger of spotlage. "After 1875 the good times eame to an end. The rull force of free trado wa folt and Amorican whest exports began to flood the English market. Grain also poured in from Canada, the Baltie, and South Russia." 23 Agrioultural condstions wore not unlik those days of the early part of the Vietorian Age.

The depresition $\angle \overline{18} 70$ 's and afterl whe due to low prices. It wes, up to 1884, malniy the prices of oorn and wool whieh were accountable. But thore was a veries of bad sensons in the 'seventios, the yield of whent haring beon below the average in seven years out of ton. The acute stage was reached in 1879. known as the 'blaak year,' whon the harvect was the wor of of an in the second half of the century. Instead of advaneing, prices fell, in eonaequenee of heavs imports. Amerlea had a creat crop. and shipped to Bngland anch greater quantity of wheat than in any provious year. Again a dist strous attack of hoep-rot carried off large numbers of animals, while foot-and-nouth di soase caused further Losses. Thus all classes of agrieviturtsts suffered. Thousands of farmers were neariy mined. 24

The ehanges which took place in the fleld of agriculture definiteiy had an acute freet on the farmers and egrieultural labourers themelves but more Inportant, Auctuations in agrieulture affected ach one of the soctal elasses in England in sowe way or anothor. It is this impiet on the olases which is stgnifloant.

23

Briggs and Jomlan, ap. att. p. 154. 24 Tra 111 , op. elt. p. 806. 
The Enclosuze Movement was considered an cononte success. It wa thought to be a major stop forward in the fleld of agrieultural dovelopmont. Lundlonds or landomers galned beause the enclosures of comon Iand Increaced produetion and raised the standards of aultivation. Inereesod production meant greater yleIds and more profits for the landownexs. The imnediate offect was detrimental, however, to the tenants and farm Iabourers.

Enclomures had negative ffect on the general condition of the labouring popalation of Englend. Mary Individnals who had been earning a Iiving off of comon land wore asolgned too littlo land to maintain a sall 21ving, many falled to ahere to their legel rights when they didn't get as much as they should have 25 and others sold thos allotmonts before or after awarde were mede. 26 "That land wes enelosed with 11 thle pect for the rights of the weaker parties cannot be denied. In many cases, these private potitions were drawn up by the principal landowners 27 of a distriet moting in georet, and the inhabitants loner litble or nothing of the detalls watll the Aet was pased" 28 For mans. primarily the landcumers, the Enolosure Hovement was extremely benerlelal and moh profit was gained. "But in the midst of this progross and growing prosperity the postition of the agrioultural labourar rominad aross and singular blot

25 Legal proeedures were too expensive for the compon Iabourers. 26.7ra111, op. ext... 103.

27 Refors to petitions to have land ondiosed. 28 Brigs and Jordan, or. 소. p. 131. 
on the nation." 29

Such a pattern of eontrast betwen the landlord:a and labourers appeared again durting the ninoteonth century when the Com Laws were still enfored. Whtle the landowners gained the comon people suffored because the price of whot wes kept artifielally high, The Com lews brought proflt for the wealthy and causod hardships for tho poor. Whilo Corn Law's wero enforced landorners could ask a high price for the wheat they sold. knowing their produot was dometiesliy moch in demand 30 the Iabourers, Individuals who Iived at the subsistenee level, had to buy wheat products [Fod staple] no matter what the cost. When Com Laws kept wheat prices high labourers went hingry. Thus a constant dispartty oxd sted between the rieh and the poor classes.

In the elghteenth and ninoteenth centuries, weslth divided individuals into soctal elasses in England, Iandomers ware considered Woh ana therefore in an uppor soclal category: fam labourers were almost alweys poor so they belonged in the lower class. Categorizing Individuals in any scolety by means of Income was not necessarily eccurato but novertheless it was the system most frequentiy used.

In 1815 Patriok Colquhoun pablishod a population surroy in which he Ilsted Brition oftivens according to class and income. Busing his ostimates on total population of fourteen millien, Colquhoun broke down the classes in the follouling nanner:

29, J. Evans. The Vletorian Age (Loncion, 1950), p. 183-184*

${ }^{30}$ Com Lews prevented foreign whent from flooding domestie markets, a atuation which would eave prioes of wheat to fall. 
Roughly min milions were assigned to the working classes. Inoludims paupars and vagrants, threo millions to the freeholders and farmers, three-quarters of a militon to the tradors and ompleyers, half a million to plablie employees and the professional olass together. four hundred and thirty-soven thousand to the eless of Imiseopers and publieans, and four hundred and twentyIive thousand to the axistocrecy" 31

It mast be kept in mind that Colquhoun's figures are over-weighted beanse bo Ineluded domestic servants among dependents but his ststisties 2re the best available from the poriod. HL material 1IIustrates that during the eaxly years of the ninoteenth eentury, the soeial strueture was dominated by the artstoevaey and landowmers. The only other major portion of tho population consists of the labouring class. These two large sectors of British soctoty had littlo in eomon and contrested gxatly.

Wealth. Porer and Pesoureas of the Brtten Enptre 32 published by patriek Colquhoun in 1815

Clase

Insogra

Antstoemey (Nobility, Comtry, Royalty and Uppor Clergy, not Ineluding next group)......................... *

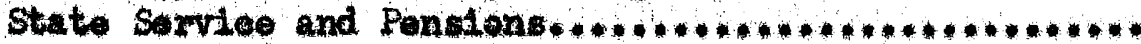

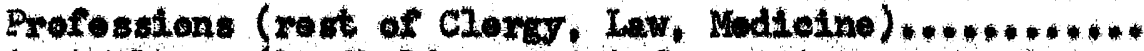
Agrienl ture (Landholders apart from aristocracy, including trecholders and farno*s. but not inoluding

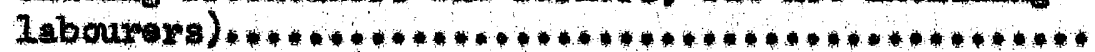
Trado and Industry (exeluding innicepers and publicans,

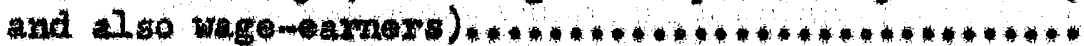

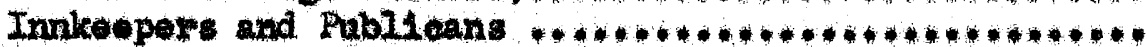
Working Classes (artisans, labourers, biners, te., In-

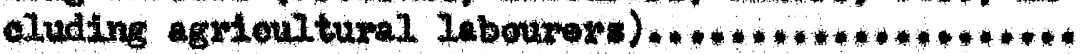

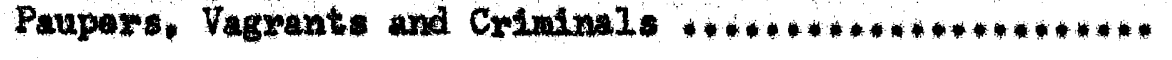
If (in prounds) $60,000,000$ $8,000,000$ $17,000,000$

$74,000,000$

$37,000,000$ $9,000,000$

Total Ineoue $\ldots t 297,000,000$

${ }^{31}$ Cale and Postgete, ap. eit. pp. 245-146.

32 Souroe cole and Postgate, op. alt. pp. 144 and 145. 
There wa sooial pyraid in Inglend and within this fomation the aristocray rested at the top while the country people, the poor or ocmon people, formod the foundation. Wealth or the lack of It divided the sectors in the social scele. The social framework was statio and inflexible. The landowners made profits and did well; "the prineipel duty of tho poor wa to be content with thel. lot." 33 All the varlations of social statur between the rieh and poor depended on gradations of income. During the exly days of the nineteonth century. Indugtrialization was in the early stages of development. The "nouveaux riche", mon who made their fortunes as morchants, factory owners and speculators, had not yot become a jor portion of British soclety" 34 In 1832 when the Great Reform BIII was passed, the middle class did not even hold office. By mid-century and particularly from $1850 \mathrm{on}$, the history of England became the history of the middle elass. They vere to become very importent sector of the British soelal stmeture during the last years of the Vletorian Era but they mast be ruled out s an importent element in the days of early nineteenth century, Rorentio England.

Since there was elear absenes of middle closs during the formative years of the Victorian Age, the difforences between the upper clesses and the lower elasses became even nore distinct and obvious. Unless the social classes are defined any discussion about them 33 Asa Briggs, The Making of Moderm England (Now York, 1959), p. 13. 34 tater, when the nembers of the middl olass began to acorue great mases of Industriel wealth, there a threat to the aristocracy for the division of classes wes supposed to bobased on woalth. Often the industrialists had. nore actual income than long, stablished and titled arlstocratio families. 
becomes vague.35 In the stratifled Viotorian social pattern, the term class meant "a category of persons who ocoupied similar position on a hierarchical seale of cortain characteristios such as wealth." 36 How much income or accumulated wealth a person or family had detemined into what soclal category he would belong. Reforring to Colquhoun's statisties Lee table on page 15 this text , the upper elasses would inelude the nobility, gentry, royalty and upper olergy. The low elasses Ineluded artisens, lobourers, miners and agrieultural labourers. Colquhoun's figures might be extended so that the eatogory Agrieulture (Iandowners apart from aristooray) bo inoluded as upper class mombers and also some Professional men, esperially the remainder of the clorgy not included in the aristoeraoy. Whon such adjustments are mado to colquhoun's originel computations, there is an oven greater disparity between rioh and poor. upper and Iower olass.

A revised table by adjusting Colquhoun's statistics would divide the upper and lower elasees in the following manner:

\begin{tabular}{|c|c|}
\hline Upper Class & $\begin{array}{l}\text { Nobility, gentxy, royalty, } \\
\text { elergy, and landomors }\end{array}$ \\
\hline & $\begin{array}{l}\text { Artisank, miners, and I } \\
\text { Iaboarers }\end{array}$ \\
\hline
\end{tabular}

Such division would separate the two elasses, upper and lower, into those who owned land and those who had no land at all.

35 There it considerable undertainty about assigning any particular individuel to a elass or status group. At best the divistons can be mado arbitrarily.

36rolf Dahrandorf, Class and Cless Confliet in Industrial Soelety (Stanford. 1959), p. 1x. 
Tho uppex elase of Victomian Bngland Included the wealthy and those who may have boen considered to be wealthy bocause of omorahtp of Iand. title, heritage or elaim to poyalty. England in 1832 resembled the emater, pre-industrial, prendemoaratic, unreformad England of the olghteonth eantury 37 It was this, the ways of the ofgteonth contury, whith Iingered on the top of Britidh goeloty well into the ninetionth cantury.

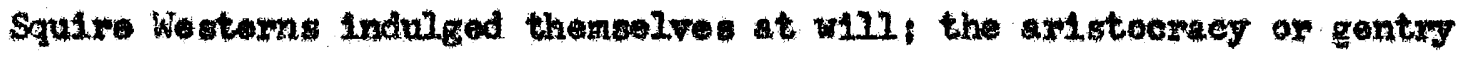
romatned unohanged stnce the days of Howlo Hngland. MTho poor had arfered by the war but at no persad had the Janded gentry been wealthier or happler. or more angrossed in the I1fe of their pleasant country houses." 38 The

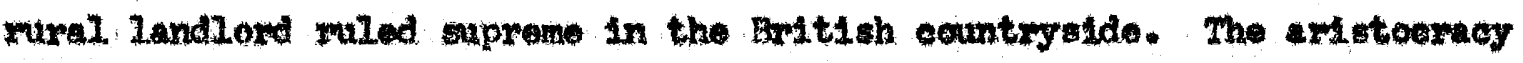

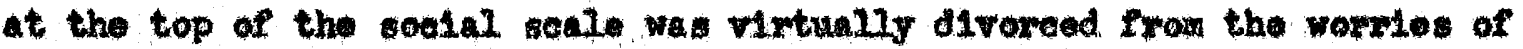

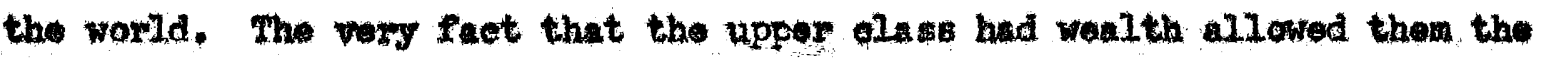
froedon to explowe the plensures of the lelsure elass. They hed both the time and the money to munt the fox, to Arink fine wines and berrs, to travel to the Continent on Grand Tour, to spend money lavishly on thenelves and their friends. The unfortunate aspect of the mamow in whtoh the upper olass Iived was that all too aften thatr weilth and fros time sas had at the oxpente of the poor. Iabouring elass at the bistom of the sootal sonie.

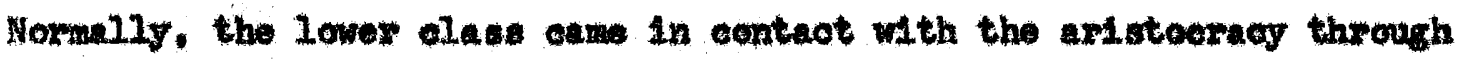

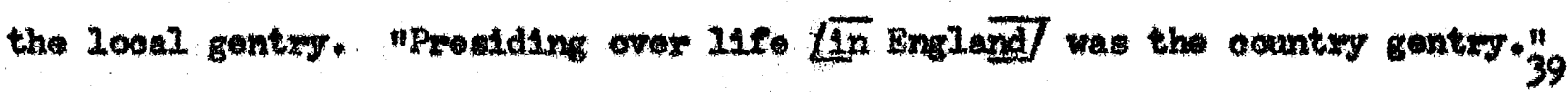

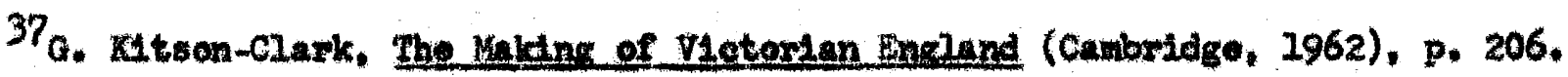
38 Refers to the post-Napolente Wr perlod, approndinately 1815 to 1839. 39 Kitson-ciakk, op. elt, g. 221. 
"The eonventionel 1dea of an English squire of elghteenth and -arly mineteonth entury seens to hav a Iiterary souree; he was either 1deql1zed as a bonovolent despot or zegarded as a drunken sot." 40 Country house or mannof house Iife moant eare-free. faxed Iiving for the sountry gentry. Mrar more characteristic of the losser squires, distributed over the oountryside In smug ostates was the rol-Ilfe figure of a self-eentered: country gentliean whth a dlettante intorest in the arts, a shrewd lntoreat In agriculture, and an onthustasm for fleld oports" 41 tho squire led a Iffe not unlike that of a plantation owner in the South during the preCivil War days of eaxly Anoxican history. "Although be travelied on the Continent and mad oxpeditions to London from time to time, the squiro's ral Interests wore bound up with his nalghborhood, his family, fritends and dependents." 42

The squire or gentry shared certain characterlsties with other upper elass individuals, According to Colquhoun, this would pertain to the nobility, rayalty and elergy-all landowners. Thele weal.th was derived from the 8011; they were often farmers themselves and they $11 \mathrm{ved}$ and worked among their poople and were interested in sports rather than pressing social issues.43 In actuality the gontry lived in a world divorced from the ways of the vorld. The gentle ways and courtily customs of the oighteenth contury Iingered on in the squirarchy at the top of British soolety.

40 MitehelI and Leys, op. oit.. p. 383.

41 bid.

42 Ibid.

$43_{\mathrm{E}}$ ame Wingfleld-Stratfond. The Vietorian Grele (Now York, 1935), pp. 9-20. 
Gentlemen members of the upper cless had so much wealth they. were, as a regult, left with great deal of leisure time to spend on themselves. Most gentry we above all constdered 'manly.' "The manly man was a hard flghter, hard rider, a lard 11ver, a hard drinker, a hand swearer and hard lover." 44 . This was a.17 the gentry had to do to amuse and entertain themselves: fight, rlde, live, drink, swoar and love lavishly. There were still a good number of gentlemen who could be desoribed as Squire Westerne remaining in the countryside. Ioft-overs from the days of the ighteenth contury.

Upper class women often had nothing to do but to be approved by man and "to realize the type of female perfection which the breadorinnor of the femily expeoted to find in his wife and daughters "45 While their husbands were off playing, hunting and enjoying thomselves, the feminine sector of the country gentry were left helploss and th nothing to do. Young ladies were often tanght by a privato governess and wenever possible did s ilttle domestic work as they could. These womon were supposed to be aequiring the social meners and customg befitting thelr higher station in the soeial seale. Ladies of the gentry had little los to do but read pootry, repeat local gosspi and await gentlemanly attentioms. Courting and social graces occupled much of their time. It was the hall-mark of a Iady' to be $1 d 10.46$

44 Wingeleld-stratford, op, att.. PP. 13-14.

45. M. Trevelyan, IIlustrated Engligh Social Hotory, Vol. 4 (New Iork and Londen, 1949-1952), pp. 23-24.

46 1b1d. pp. 24-25. 
"Upper class definitely meant gentloman or gentlewowan and something bestdes; and the profix gentle had in most people's minds definito rolation to family antecedonts as well as to ocoupation - or to the absence of 1t."4q At the vary top of English society wa a body of heroditartly titled individuals. There vere very fow of these people because their only clain to uppor class status was a t1tle. However, the titled axistocracy tonded to mary into the sooial class immediately below thom. Titled married now wealth in order to bolstor the ranks. Many of the se 'secondary! familles were the lower ranks of the aristoeracy - the landed gentry just d1soussed.

The gentle elass considered thenselves the landed, privilegad elite and had no doubts about the rightness of thelr clalns to superiority. Tho Ilfe of the manow house, the only ilfe they over knew, oould only have been theirs had they not titile, land, noney and the lis sure time provided. by their wealth. This attitude of ouperlordty increased the alroady ex1sting tonglons which were ovident between the upper class and the lower eless. Espectally in agrieultural ameas, the upper class and lower elass cane in constant contect with oach other. The landlogs poor were mado to feel oven more domntrodion when they saw overy day their masters sporting at the expense of their labourers who ouffered. The rloh corld concelve of Ilfe in no othor fashlon. The only manners they know wor those of the wealthy and lelsured elass. Their days were full of hope and Iffe moved on at relaxed pace. The lower oless never knew such an exdstenge. Thoy had suffered long onough; thore had to be a change.

47. D. H. Cole, Studies in Class Stmucture (London, 1955), p. 61. 
What a eontrast there was betwen the suntuous mamer of upper elass Iffe and the way the Lower, poorer classes existad. The poor could afford little tim to play for they worked from dawn till dudk. Women wore far from idle; they worked right along with the men in the fields, dairios, grape arbors and pasturelands. There was no wealth and vory 1ittle incoine nong the poor workers. They owned no land and they worked and toiled on the land which belonged to others. Land was the basis of status and power in Vletorian Ingland. Land mont walth. The rioh had it and the poow had not. Betwen the two elases was a barrier of Iand, It was on this land, tho agrievltural flelds, where tho upper class and lower elass in contact and yet that very land kept them forever ceparated. Land was the battlefield between the olassos.

Fow the common labourex the whole periad 48 was a time of depresiston and loom, often was and ineome obtalned from mag garden plots were so low that the poop on the very dge of starvation, defenseless agalnst 117ness or the slightest wisfortune " 49 The broadwinner in a poor family durling hard times had no alternstive but to watoh his family ouffer. If there was a crop fallure it meant unemployment which nesulted in no incone to pay for food for the hungry. The lower elass was made more acutely awam of thelr plight when they ompared the stuation they found themselves faod with to the luxurles of their upper class landlords. It wes bad enough that they should be IIring at the barest level of exdstence but it seemed worse when contrasted with the ways and mamers of the rieh. 48 Refers to the early deeades of the nineteonth oentury in Englend. 49 Mitcho11 and Leys, op. clts. p. 387 . 
In the postmwar years of prosperity for the upper class, the lower olasses lived at the subsistence level or below. "In visiting the Iabouring families," wrote Rev. David Davles in the Cage of Labourers in Hasbandry. "I could not but observo their mean and distressed condition. I found them Indifferently fod, bedly elathed, some ehildren without shoos and stockings, very fow put to sehool..." 50

Actually once the Napoleonio Wars were over the agricultural labourer was doing woll, if real wages are considered and taking the average of the country as a wholo.51 "In some regtons he was docidely better off. But his legrioultural labourer standard of life had declined In those parts of the rurel South which lay farthest from the wage- competition of factorles and inines, particulariy where the poor-rates wore being employed to keep wages down, and where the labourer depended on the landowner who arployed him," 52

There was a distinet differenee botween the conditions of the egricultural labourer during the ighteenth century and during the ninetoonth eontury.

The agrleultural labourer during the early nineteenth century wes often foreed to take part of his wages in bad corn and worse beer. In earlier and simpler days the Iebourer had more often been lodged in the farm and ate at the board of the landowner. This had mont a - loser and kindor porsonal contact and less segrogation of classes: 53

50j. F. C. Harri son, Ed., Soetety and Politics in England (Now York, 1965). p. 35 .

5I Real Wages: The non-agricultural sector of the cconowy was in a depression so the labourer's Ineome of dollar would buy more.

52Trevelyan, ope oft., pp. 8-9. $53_{1 \text { bid. }}$ 
After the Napoloonio Wars there was a long period of hard times for the poor in England. Agrieultural workers in partloular suffered from the severe conomid oonditiong. Industry no longer produced muntions so war-tine Industrial workers had no jobs; soldiers back from the war came hame to find no work so the unemployed clooded the laboux ararket. In addition, bad harvests meant starvation everyahere. The profits gejned by the rich or upper alass only accentuated the downtrodden lower alass poor and their bifighted condition.

The great majortty of the lower classes was undexfed, poorly housed, underpald, had no partleular powers or value to soclety, and was ignorant and 1711 terate. 44 "Between the jears 1802 and 1832 the existing system of Buttsh farming. by whleh land wes owned by landlords, oceupled by tenants, and culttrated by labourers, becara practieally univerand." 55 It wes under such IIving eonditions that the poor guffered and the rich thrived. Constantly in oontact, the upper and lower alossos conflieted over the every-day problems of ext tence.

The class gystem in Groat Bxitain during the Viotorian years was extremely structurad and stratified. Not only was thore a great disparity between wloh and poor but there was very I1ttle opportunity for social mobility either up or down. This inflexibility further aggravated an already Intolerable situation of social inequality in the eyes of the Iower class. The prosperity of the upper class served to acentuate the

54. Evans, op. ofte, p. 187.

55 Traill, ope alt. p. 102 . 
fact that the lowe clesses had nothing. In addition, the upper class often acceoded at the experse of the dowtrodden poor.

\section{II}

Thomas Hardy, Victorian author, revolted against the elass consciousness in Brltish soclety. Because Hardy was originally from a very mural and romote pert of ingland his most frequent contacts wero primarily with lower elass unsklliad agrioultural labourers. It was with these poople that Hardy's sympathies reated.

Born in 1840. Thomas Hardy grow up in Wessex, an agricultural. localo in the southwest comer of England. Hardy"s birthplace was "a small cluster of tiny cottages, set off only by the inevitable tavern. It boasted neither church. school, nor post offles. No main road ran through 1t. Dorohestor 1tsolf, not yot tapped by rilway 1ines, was Eelf-contained enough but Upper Boekhampton was virgin, untouched by the steel of induatrial oulture, primtine, natural." 56

Growing up In and around Dorohester put Handy in contact wh individuals whom he would never forget. His daily assoclations were with farmers' chlldron, local shopkeepers, dalry majds, tavern keepers and the 11ke. The se individuals wore mastie and unspoiled, untouchod by the whels of modern Industry. In many ways they were flety years bohind tines and yet thi primitiveness 18 what endeared the poople of the area to the heart of the author. There were certein quallties about

56

Emest Bremeake, It. The Life of Thomes Handy (Now Iork, 1925), p. 77. 
the possant rolk when spolled upon contact wh the upper cless.

The people of Wessex ware slowmoving, clothed in weather-worn garments whose out, like the out of their pro-nouns, had searealy changed In generations..." 57 Sheh individuals were the dominating factors in Hardy's childhood. Identifying as he did th the downtrodden and poor, Hardy hinself hat feelings of elass consoloumess. As he grew into hanhood he found himself caught in a dilema; to which class did he trily belong.

Thomas Hardy came from a family with a mixed social beckground. Els father sta comon labourer and had made his living as a stone-mason. The fomily anoome was modest. On his father's stde of the fanizr then. the Harlys constdered themselves part of the lower, Norking olsss. Hardy's

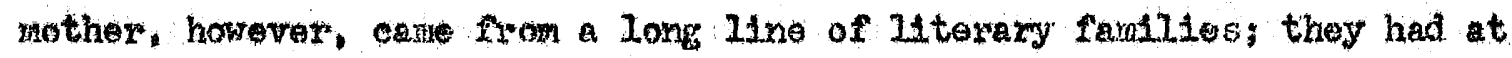
one time had considerable wealth. In this respect, his famly on his mother's side lalmed to be upper elss. However, "on both silds of his fantly the LooleIt progression had boen downard. From a postelon regarded by Vlotorian soolety as nore werthy, that of landed propriotorshtp. the descent to the 1ow thatehed house on the edge of Egdon Heath ths one that Hardy foind hard to foxget." 58

In one respect Hardy orew up in atmosphere of artifiolal and pretentious uppos class values. At the ame time ho developed in a vorld peopled by gemane farm Iabourexs tled to the earth by their work and their poverty. Caught In a pull betwen the two ands of the social reale. Thomas Haxdy' foelings bent towards the matic lower class.

\section{1bla.}

${ }^{58}$ Car1 J. Weber, Hardy of Wegsex (Hamden, 1962), p. 7. 
Caught in elass-consolous dilemma. Thomes Hardy lived in two worlds! his life was a double one. He lived both in the worid of the woalthy and leisurely upper elass and yet know the realism of lower class life as well. Mhardy spoke with a Dorset occent, and he lonew tho mural dialect, but as a boy he was not permitted to spoak $1 t . " 59$ Although Hardy associated th the nural people of Dorehester. His mothor was too conscious of overy mark of social inferiority to allow hin to label himsolf by the rustle vocabulary " 60 When Hardy played with the youngsters in his area he acquired tholi hatsts, manners, language and rustic ways. His mother and father frowned on swoh oustoms and would not allow him to bring his lower class associates into their home. "Hardy soon learned that there was an invisible but distinet barrier between the lifo within his home and the life outgide 1t."61 This difference was the same as the barrier botwon the upper and lower classes. At the same tim as be was growing Into manhood Hardy learned another important lesson about English society. Not only ws there a difference betwen ilfo inside his home as compared to If outside the home but that very distinetion made it clear to Hardy that there was a very clear barpler between the agricultural ife of the lower elass individuals whom ho knew wall and the landed gentry known to hin as the upper elass. From oarly ohilahood Thoras Hardy formed the Ideas about classes and class consoiousness whioh appeared in the novels he wrote as a mature man.

591b1d. pp: $19-20$.

60 1bia.

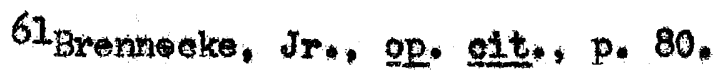


No exact dato an bo sot for the first daming of a sense of social distinotion in Hardy's om mind, "but it was there before ho had reachad the age of ten; axd, once plantad in his nind, it never left hin." 62 Ag Hardy grow into manhood the influence of his parents' social class conselousness becme more pronounced and this in turn caused Hardy to becone Introspective and lonely. Te knev not where to tum in his desire to Identify vith some facet of the soclal pattern. He criticized the socioty in which he Ilved ho expressed hts orlticism in his novels.

Mardy's first rovel, entitled The Poor Men and the Lady, onphasized throughout its actions the soclal dispartty announcod in the title."63 In An Indiscretion in the Life of sn Heiress and again in his Iater novels, the recognition of class disparity weighed moxe and more heavily upon him. The cales he drote in the olghties and nineties roflected his early inpressions of social djseord.

"It Is important to reallze the oariy a ppot of Herdy'g Iffo for

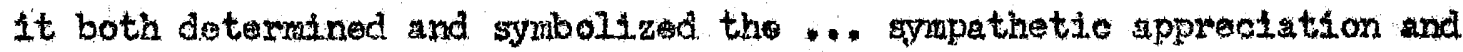
pity $[$ for the lower clases which was later on to eharactertze his whole artistic attitude."6/4 The same theme of social conflict between the classes was ovident in the fetum of the lative written in 1878 and in his later novel the payor of Casterbridge, 1886.

62 Wober, op. olte, p. 5 . 63 ibid. ${ }^{64}$ Bremmeck, Jx., pp. elt., p. 81 . 
The pariod known as the "Hungry fortios" expertenoed by the agricultural workers and labourers greatly impressed author Thomas Hardy. Wessex was a Locale which existad from cay to day on agrieulture ard depended on food for the viliages from agricul taral production. whe conditions of the Wessex region sullelified in the mind of thomas Hardy and inpressed upon hin the precerious extstence of Wesser agrieulturel Iabourers of the Lower clase. Whan he was only ten Hardy knew a boy from his rogion the had starved to death during the fanine years tho agrioulturists suffered 65 Hardy's sympthy for the matic heart grew over the J6ars. In 1891 then many people in prosperous, Industrial ingland belloved class differences had been rectifiec, Thomas Hardy saw that one inportant aspoct of British soeiety romalned unchanged. Claso distirotions ore as cloar cut in 1890 as thoy ware in 1815; only a slight transformation had taken plate. Hardy saw that the formex upper class, now in a high income bracket because they owned the factors of production, the same type of individuals who had boen the landed gentry fifty years previous. The Iower class. Instead of being agrienltural labourers, wa raplaced by Individualg who were just as distressed and in the same soclal category. the factory worker"66 The situation of a wide ecp between the upper and lower classes still oxisted but with the onset of the Industrial Revolution the characteristics of those two classes changed. There was st111 a stratifled elass systom in England, and as a result there was stil much eonflict betwen the uppex and lower classes.

65ober, op. eit., p. 14.

66 England at this time was primerily an urban nation (1890's). 
"Haxdy drematized the evil of elass feeling--how "honest human affection w1Il bocome shamefaed and moan under the frost of olassdiviston and sootal prejudices'--in nearly all of his storles and novels."67 In each novel, desp1te the major thome of moral1ty, Thomas Hardy stressed the continuous exdstence of elasses and the destruetion such stratification eaused to human beings. When the elasses wero pitted against each other. constantly in confliet, it was the lowor class that surfered the wost. Hardy strongly folt that the uppor olasses had a detrimental affect upon the lower elass rusties. Whon thoy came in contect it seomod that it was the lower elasses who suffered at the expense of the upper elass.

The two novels in which Thomas Hardy most strongly voleed his opintons about lass and olass cancolousmess in Viotorian soolety and the Injustlees such distinetions brought about vero ress of the durberIIles and Jude the Obgoure. The poor, Hardy believed, were coarse but had the virtues of fldelity, simplicity, enduranoe, and toloranee. They were stmple but pure. However, "this maxal simplietty was threatoned by arloteoratic complexdty."68 The simple musties became tainted and lost their virtue whon they came in touch with the complex Iffo of the upper elass, The poor were corrupted when the two classes, upper and lower. conflieted. In Tess and in Jude are numerous examples of the upper and Iower classes which Hardy felt so intonsely sbout, He wove storles about the day to day lives of the comon as woll as the upper elass peoplo of Wossex, diseussed examples of when and under what conditions the two

67 Albert J. Guerard, Thomas Hardy (Cambridge, 1949), p. 24. 68 1 bid.. p* 20. 
classes came into contact with each other, and why they olashed. Both novels, Tess of the durbervilies writton in 1891 and Jude the Obscure in 1896. wore sat in the agrloultural atmosphere which Hardy knew well. It was his techntque to eriticize the current soclal pattern by writing novels which were storles bout the people who lived in the days of very oarly Victorian England. This was his advantage as an authow, however, because Hardy wrote best about the people and the aree with which he was nost famlilar. Ho truly ontered the hearts, minds, and feelings of the Wessex population. H1s portrayals of sueh people and theis problems, in turn made 1t possible for Hardy to onter into the foelings of his contemporamies. Tess and Jude wore cxiticlsms of soclets of the past but the two novels also deal with the contemporary world and probloms of Hardy's wature years 69

The seene of Herdy's novels is ostablished in an agrloultural sotting in or near his home area of Dorchester in Wessex. Within this setting Tess was written; Hardy had two reasons in mind. First, he wantod to arouse sympethy for a virtuons girl who had a tragio 11 fo because sho had been unjustly seduced by member of the upper class. Secondly. Rardy hoped to make clear the unfalr troatment the lower clesses suffered on the acoount of the uppar olesses. It was in a maral setting that Hardy oould best deseribe the contects which $708 \mathrm{~s}$ had both with the simple, 70 rustio ways of 1 ife but also with the superfleial mamers of the upper

69. David Ceotl. Hendy the Noveliat (Iondon, 1960), P. 18.

70 This 2 lso gave Hardy an opportunity to say somothing about tho doploralo situstion of British grieulture in the nineteenth century. 
elass which Hardy so strongly resentod. He not only mypathized. with the downtrodiden but stated that when the Lower alisses oum into contact with the upper clesses, the poor ware sure to suffor because of the association. Tess" Iffe had been destroyed as realt of her contact With the upper class roue, Alec diorberville. Whe beautiful innocent maidon, Tess [Fopresentative of the lower alags was betrayed by a wioked seducer [rofors to Alec of the upper olass and onded her I1fo on the gal10* troo." 71

Thew are numerous examples in Tess whteh oonfirm Hardy's pht1osophy about the social clases in Vlatorian England. "A fow vory noal problems recur in most of the [ExayJ novels and provide a formal subject meter, the contrast betweon rural simplielty and arlstooratic eomploxdty and commaption, the pathos of rogional and olass deracination. and the destructive frect of clase reoling." 72 Tess herself represents the simple matic Hardy me meh admiro and individual Iike Alec are upper alass personalities with whom the lower class cons Into contuct. The olasses represented in the two Hardy novels, Teve of the d'Urbervilles and Jude the Obsaure, In the author's mind stood for very specifle elomonts in Bntish oolety.

The upper eless in Hardy's novels referted partioularly to the resmants of one-wealthy and titled fandly. The 'mallor gentry' still were constdered Iandomers and had all the ccouternents of the ardstoeratio

71 Ceo11, op. elt. p. 32 . 72 Guerard, op. oit., p. 19. 
gentry but thoy st117 represented, in comparisan to lower aless workers, the upper stratum of Butish socioty. Class status was a relative toplo ind even though the gentry were, In Vietorian soolety, on the way doin the social ladder, In the oyes of the lower eless the gentry were considered to bo the upper olass. The gontry or upper olass incone camo from ownership of land. Even though thoy wore not extromely wealthy, in fact, they sonotivs were relatively poor themselves, they wor novertheloss wealthIor than the working olass poor.

The entire setting of Teas of the d Urbervilies was an igricultura one. Shaston and the viliage of Marlott plus the adjoining region of Bleckonor ade up the locale in whtoh the eptsode took place. Hendy desoribed his mative Wessex whon he wroto:

The village of Marlott lay amid the noxthosatom undulations of the beautiful Val of Blakemoox. of Blackwoor. aforesald, an ongtrdled and soeluded reglen. for tho wost part untrodden as jot by tourtet or landacape palnter, though vithin a four-hour Joumey froen London.73

It was in an aree quite simflar to the terwitory in which Hardy had grown up, that the representatives of both the upper and lower class 11ved. struggled, and died. In Tess of the duybercilles the upper class gentry and lower class Iabourers of the fame wore in froquent contact with each othor due to the fact that they both I1ved in a ruxal, agrioultural regien.

Thomas Hardy manfprlated the sotting of the novel, Tess, in 73 Thomes Hardy. 3ess of the d'Urbervil1es (Hew York, 1964), D. 22. 
order to argue his ldeas about the stratiflod systom of alas distinetion whioh ho saw not only in the Sngland of the past but in the latter part of the nineteenth century as woll. In a maral area both upper and lower class individuals were dependent upon the land in some fanner for their vory oxtstonce (upper and Lower classes). Although the labourers no longer lived and ate on the promises of the landed gentry as they onee had done during the days of the aighteenth century, the poor and the worlthy did cone in contect with oech othor. Uppor cless individual: hold positione of loeal Importance and often had somo sort of supervisory. poters over the poor. In the case with Toss hergelf, her family of farm labourers obtained word that they had a legal olaim to a titled family-the family and name of dUrberville. As a result, Toss is actualiy sent to sook out an upper class relition so that she might 'clatm kin.' This was a rare instance of upper and lower alases rolating to each other. but there were way other examplos in the every-day pattorn of Iif in mastic Wessex and the nourby regions. Quite often whon tho lower alasses were in want due to amine or crop fallure, they went to the landomers to express and, hopefuliy, to fulmil their needs. The gentry wer paternal oversears of the lobouring lower olass.

In Tess of the divrberntiles Hardy assigned two characters to the landed upper olass gentry: Aloo ditrberwllle and Angel Clare.74 the euthor's attack on the upper class originated with desoription of the titled d'Urbervilies. Instead of being logitimate claimants to aristocracy.

74

It seems 1ronie that both charactars aren and lead to the destruction and eventual domfall of female momber of the lowem class. 
the family's source was from a merchant who had adopted an jmportant sounding name so that it woold appear that his family was aristocratic. In other words, they wor inpersonators.

The dUrberville-or stoke-divrbervilies, as they at flrst ealled themselvos-were a somewhet unasual canily. When old Iir. Stmon stoke had made his fortune 28 an honest merehint in the North, he decided to settle as a county wan in the South of Ingland; in doing this he folt the neeessity of recomencing wth a name that would not too roedily identing hin with the mart tredesmin of the past and that would be leas commonplace than the orlgknel beld, stark words. He coneldered that durbervilie looked and counded as well as any and d'frbervilio accordingly wes amexed to his own name for himself and his helis otomally 75

It wa Into such peoude-ariotoeratie family of d'Urbervilie that a son, Alec. was born. In his deseription of Alec and his subsequent bohavior. Thona Haxdy very vividly portrays his feelings and sontinents abot the upper alass. Haxdy reinforees those denuneiations whon ho disoused Alea d'Uxbervilie's contacts with not only Tess but the ontire vilage of the rusties of Marlott.

Aloc d'Urberville ws typieal of the upper olass gentry because he had title (even though adopted). fanily horltage, money and los sure. He was rockless, hard-living, a oad and a playboy. He could best bo deseribed in one word-roue. Alec was a olgar-smoking, rleh young vulgartan who lived only for his own animal pleanure "76

75 Hardy, Tess, Pp. 50-51. ${ }^{76}$ coc11, og, atte. p. 115 . 
Ho had an almost awarthy complexion, with fall 11ps, badly moulded, though red and smooth, above which was a we1l-groomed bladk moustache with curled points, though his age could not be more than three- or fourand-turenty. Despite the touches of barbarism in his countours, there was a singular force in the gentleman's faee and in his bold rolling oro 77

There seams to be no doubt that Hardy consldered Alec as the villain In his novel. Tess of the dUUrbervilles. He let Alee dUrberville reprosent all that wes corrupt and ev1l in the upper classes. It wes the character Aloc who sedueed Toss, L Lwer olass farm girl. whom Hardy called ra pare woman. 1 Not only did Alec take advantage of an innocent mist1e but in addition he showed I1ttle concerm for the consequences of his actions. Hardy, in the character of Alec, very elearly points out that he folt the upper olasses were often irresponsible and were unconcorned for the fate of the lower elasses. When the upper ant lower elasses did come into contiget with oach other, and as a rult conflicted as did Alec and Tess. 1t was the upper class individual who survived and the lower elass person who was to suefer because of the relationship. Irrosponsibility and a lack of concern for the outcome of their actions. ospecially when those etions had to do with the lower elasses, were sins of the upper alass which Hardy could not forgive. Therefore, he wrote about them and exposed them to the reading world.

In Tess of the d'Urbervilies Hardy's sympathies were with the comon agricultural labourers and tholr families. Before Tess came in contact with Aloc, hor family name had been 'Duxbeyfleld' and considered

77 Hardy, 2ess, p. 51 . 
themselves to be no higher in the social scale and no higher in social importance than the lowest member of the societal ladder. Haxdy wroto Tess from the common man's point of view and wroto criticlizing the values of the upper clesses. He considered the existocracy hypocritieal and artificial compared to the genulne wholesomeness of the lower olass working people.

A sense of injustice against the pure strple rusties is portrayed in deseriptions of Tess, her family, and the villagers of Marlott.

Why it was that upon this beartiful rominine t1 ssue. [Tess] ... there should have been traeed such a coarse pattern as it vas doomed to rocelive; ... many thousand years of analy tionl philosophy have falled to explain . " 78

Hardy belfoved the agrieultural labourers, the poor lower class, were takon advantsge of by the uppor elesses. The coarse pattorn traced upon Tess was the ireprint of Alec d'Urbervillo's rash actions. Hardy was disturbed by the fact that Alee never had to pay for his eximos but Tess, who was unaware of the troublo she had gotten into, suffered the remeinder of her life. Thts was the injustice in the social system as Hardy saw it. Tess and hor lower eless relatives eame in contact whth one other example of the uppor eless whtch served to solidify ferdy's ideas about the gap botweon the classes in the minds of the reading public. Angel Clare was not quite the domon that Hardy doseribed in tho cheractirization of Ales ditrberville but there are similarities in the family bakgrounds

78 Hardy, Tess, p. 89 , 
from which both young taen originated.

Old Mr. Clare was a elergyaen of a type which, within the last twonty years, has we 11 migh dropped out of contemperary Iifo. A spiritrial desoendant in the direct It ine from Wyelife. Huss, Inther, Calvin, an Evangelical of the Evangelicals, a Conversiontst. a man of apostolie simplicity in Iffe and thought, he had in hys raw youth made up his mind oneo and for ali on the deeper questions of exdstence and adalted no further reasoning on them thenceforward. Ho was regarded even by those of his om date and school of thinking as extremes while. on the other hand, those totally opposed to hifi were wnililingly won to admiration for his thoroughness and for the remaxkeblo power he showed in dismissins all question as to prineiples in his enerey for apply them .... One thing be certainly was-sincere. 79

Alec d'Urberollie oume from a fantly of lended gontry, a family that had eamed 1ts money in the warket but acquired 1ts t1tle by hoax. Angel Clare's family reproaented the oxiglnal arlatocracy; ono facet of the uppow elass was the elergy and Angel Clare's family had lang tradition of clories in thelr horitage.

Although Angel Cleve showed signs of wishting to abandon the uppor class backround from which he came, he had not lost contact wh his family, especially his two brothers, plilars of the chureh and members of the landed gentry. Thome Herdy oxpressed his opinion of the EstabIished Church and its elargy in the characters of Angel clare's two brothers. Angel himself 1 also part of this aspeet of society but he is a vague figure bocause ho throetens to drop the ways of the uppor class, His two brothers, however, exe perfect oxamplos of aristocrats.

79 Hardy, Tess, Pp. 173-174. 
Aftar breakfast he Angel clare walked with his two brothers, non-evangelical, well-educated. hall-marked young men, correct to thelr remotest fibre: such unimpeachable models as are turned. out yearly by the lathe of a systematic tuition. 80

Hardy continues the description of Angel's two brothers by oxplaining their olerieal background.

If these two notieed Angel's growing soolal ineptmess. he notlced their growing nontal limitations. Bolix seomed to hin all Chureh, Cathbort all College. Ils Dioessan Symod and Visitations were the mainsprings of the vorld to the one f Cambridge to the other. Bach brother candidly recognized that there were a fow unimportant soores of millions of outsiders in aivilized soctety, persons who were net ther university men nox charchmon; but they were to be tolerated rather than rookoned with and respected. 81

In one brlef paragraph Thomas Hardy out through the social stratifloation of Vletorian Englind and attakked both the chureh and edreation as woll as the class gytem with a doublomedged sword. Angel Clar's family represented to Handy overything ho objected to in the upper class factor of Britiah Vlotorian socioty. This very attitude of superiority kept the upper and Iower classer separate and was responsible for the paternal attitude of the rich towards the poor.

Thomes lardy doveloped these strong foelings against both the church and Britlsh oducation in the last noval he over wrote, Jude the Obsoure. There were andl indications, previously mentioned, which

80 ibld. pp. 175-176.

81 1 bia. 
were ovident of such emotions about these institutions long before jude the Obscure was written. In Tess of the d'Urberyilies ther are several passages which give an Indication that Hardy was aware of elass distinetions In the areas of education and the chureh. The diseussion between Angel Clare and his brothers is one of them. Actulily Hardy was sympathetle towards clare primarily because Angel clare tried to close the gap which exdsted between the classes. He showed stgns of leaving his upper cless ties and fointing tho lower ranks. Thls was perhaps most clearly evident when Angel merried Tess. Angel. Clare was an excoption; he was an examplo of an upper class individual tho proflted by his contect with the Inwer classos. In Victorian society It was possible for an upper class individual to nove down the soclal sealo and in this particular case, Hardy pointed out that such a move was a benefletel ono. However, it was not possible for the lower classes to be brought up tnto the vorld of the upper aristocracy, the rich and titled. When Angel Clare wanted to marry Tess Durbeyfleld, the matd of a dairy, It was noessary for hIm to give up his family ties and go into the ranks of the lower class himself. He could not incorporate Tess into the upper elass establishment of his family. She clearly did not belong to the world of the paxsen and the scholar.

Hardy deseribed Angel clare as a mixture of upper class hablts and lower elass emotions. He was the youngest in his aristooratic, olerieal fantly and his ties to the upper class, landed centry wero very Loose ones. Fe, sombwat like Hariy, was a combination of both elasses. Hils family olaimed to be aristoeratio and yot Clare's contacts were with 
agricultural matics. Angel clare was cenght in the middle, in betteen sochal classes.

- something nebulous, preocoupied, vague, in his bearing ard regard, marked hin as one who probably had no very definite alm or conoern about his materlal future. Iot ss a Iad pooplo had satd of hin that ho was ono who might do anything if he tried o. He was the youngest son of his father, a poor parson at the other end of the country, and had arrived at Talbothays Dairy as a1x months" papil after goling the round of some other farms, his object beling to acquire practieal skill in the various proeesses of farming. With a viow elther to the colonies or the temaxe of a home-farm as oiroumetances might dectde. 82

Angol Clare was caught, not unlike Bardy himself, in a dilenma pulled between two seperate and distinct social classes. His parents wantod him to follow their oxpotations in the upper elass tradition and ho refused, henee they viewed him a firting with a futare in the ranks of the lower class. Despito his sympathies, Angel Clawo was stlll viewed by the mustics as thelo superion he was fopever upper class.

Mr. Angel clare--he that is leaming andiking and that plays the harp-mever says woh to us. Those are the cosments of one of the datyrmeld son, and is too moh taken up his own thoughts to notie ginls. He $1 \mathrm{~s}$ the dairyman's prpli--Iearning farting in 11 lts branches. Ho has learnt bhoopfarain at another plaes, and ho' nev mastening dairywork ... Tes, he $1 \mathrm{~s}$ quite the gentleman-bown. His father is the Reverent Mr. Clare at Buminater - a goad wany milos from hare.

Even though Angel Clare rejeoted the values of the uppor elass and leamed the ways of the working class, he wa never really accepted as

82 Hardy. Tess, p. 130.

83 ibid. p. 129. 
one of then. The common people olth whom assoctated consiatently thought of him as different, as upper class, as the son of a parson. Throughout Tess of the dUrbertilies Angel Clare made attempts to break away from his upper class heritage and tried to join the lower class: The material distinctions of rank and wealth he increasingly desplsod. Even the good old frmily" "... had no aroma for him ..." 84

It is difficult to assign clare to a social slat and define him as an upper class individual who came into contact and conflict with tho lower class. He did come in contact wh the poor but he abandoned his upper clese family to do so. Despite all his good efforti, however, 14 senms eles that Herdy, In the long run, considered Angel Clare to bo a representative of the uppor class who mets and corrupts the lower olass peasant, Even though ho was an ambivalent character caught in a viso between upper and lower classes, Clare followed the same pattern as did Alec divrbervilio. When his assootations with Tess proved a disappointnent to him 85 he left hor and shumed regponsibility for his actions just a Alec did. In Hardy's mind, this faet alone puts both men Into the sam oategory.

Actualiy ang discussion about Angel clare turns into a series of conflicting steternonts because ho is part of both of the worlds Hardy was faniliar with. Fexhaps the bost summary is the one Hardy wrote himself about Clare: "Desplte his heterodoxy, faults, and wealnesses. Clare was a mith anseience." 86

84 Hardy, Tess, pp. 132-133.

85 clare left Tess when he found out she was not a virgin when they wore marmied. 86 Hardy. Tesse. p. 170. 
In comparison to the lowar olass, as represented by Iess, her fanily and the village peasants of Marlott, bath Alec d'Urbervilile and Angel Qlare are clasaly uppor class ropresentatives, the case of Clare baing a borderline exception. Recalling the fact that the upper class had considerable income and the lowor class had none, both Alec and Angel had access to fantly wealth. In this respect therre was a very sharp distinction betwon the eharacters Hardy defined as upper class and the ristis poor.

Mrs. Durbeyfield, Tess mother, was an example of the wife of a typical agricultural labourex squecing out an ext.stence in a muxal and struggling community. Toss, although a lower elass Individual herself, had bopss of something botter; she saw how mothar as hopelossly oaught in the veb of degpali brought on by too nuch work and too littlo food,

There stood her wother waid the group of ohildren, as Tess had left her, hangIng over the Monday washin-tub, which had now, is alinass, Iingerod on to the ond of the week ... As usual, Mrs. Durbeyfleld was balanced in the afowesald bustines of roolding hov youngest ehild. the cradlo-rockers had done hard duty for so many years, under the waight of wan ehildren

The some type of frutless lifo faced prectleally overy individual in Wessax who had to labour on the land in onder to survive. If any misfoxtune oecurred, the whole vilage's existence was threatened, There seemed to be no question in Hardy's mind that the poor should be assigned to the loter social class eategory. Thelrs was a life of contimuous glooin and hard times.

87 Hardy, Tess, pp. 30-31. 
The staple conversation of the farms ... was on the nsolessness of saving money; and smook-frooked axthmeticlans, leaning on their ploughs or hoos, would enter Into caloulations of great nicety to prove that parish rellef was a fuller proviston for a man in his old ago than any thich could result from savings out of their wages during whol Hifotine. 88

Thore was a sharp contrast between characters such as Alec and Ange. clare and the viliage pople of Narlott. They found their Iives intexingled and yet they wexe as diatinot from aach other as black is from white.

Perhaps the most tragic example in tho stmuggle and oonflict betwoen the elasses in Tess of the durberyllios is Tess herself.

She was a Hne and hand some girl--not hand somer than some others, posstbly-but her moblle peony mouth and Iarge Imnocent oyos added eloquence to coloux and shape. She wore a red ribbon in her halr and was the onily one of the white oompany who could boast of such a pronounoed adomment. 89

The entire novel of Mess of the didrberrillos revolved around the story of an innocent rustue daughtex of a lower oless agricultural Iabouras who, despite her neiveto, was seduced and consequentiy dostroyed by hex contact with a young and sporting nember of the upper alass landed gentry. This was a vory abrupt way of confronting his readers unth an example of a serlous soctal diseasomelass divistons. The thene of Tese Was controversisl; it was "the story of a sedued girl making a rutilo

\footnotetext{
${ }^{88}$ Handy, Tess, p. 75.

89 ibide, p. 25.
} 
but herole effort to help her worthless family in blighted world, whew familses go down. down, down."90 Thomas Hardy used the technique to jar Vietorians out of their complacency and self-satisfaction with life as it Was.

The agricultural sector of British econony had reached the peak of prospertty around 1870 and many felt all social 171 s related to agriculture and the lowex classes of society hed disappenred. 91

\section{$\operatorname{III}$}

Thoma Hardy wote another noveI in 1896. Jude the Obsaure, hoping to prove to the satisfied Individuals in British society that they wore elosing thein ores to social problems which still existed. Although still very closely tied to agriculture, Hardy used the olergy and the field of education as additiongl volces fon his entilelsms agalnst elass distinetion in Eritish society. The clergy at this time was simply another aspect of the Iandowning aristooracy.

The Churoh (Chureh of England) and oducation wero very tightly knit together. Wuoh of what Hardy know about both was the result of personal -xporionce. "As a boy Hexdy had boen a regular attondent at the sorviees In Stinsford Church. Sntering the Church would have involved him in the puraut of a university education - a vagu and distant goal for a boy In a howe where there had been no previous experience with oxfond or Cambroge. "92

90 Weber. op. eit. p. 119.

91 Another reason for the complaceney of the Vletorian people was the series of Iaws whleh were passed between 1815 and 1870 rectifying social 111 s.

92 Wober, ope cect., p. 19. 
There are strong parallels between Themas Hardy and Jude Favioy in sude the Obsouxe. Herdy eloarly tolly rauch about his om lifo and his prsonal oxperiences with class distinetion and divistons as he lated the tale of a young man set on going to a university. Handy was aware of gross injustices in the church and in the clengy who wore responsible for administexing public education in England. "Ho [Hardy thought," therefore, "of telling the story of a young man who could not so to Uxion, who after herole stmaggles and ultimato failure oomitted. suicide." 93

Jude vepresents Hardy' feelings about the upper alass clergy and tholr monopoly on ducation in bngland. Also, üzde is portrayal of a lawer olass boy who was freed with living in parts of two worids. his own lowex class world and an upper elass existonce at oxford or Cambridge. There are many aspects of Jude Fawley that remind the roador of Haxdy's own background and would explain his prejudices and thoughts about the social olasses.

Thoms Hardy was bom two miles from Stinsford (We1lstook) and Jude Fawley came from 11gtoek in South Wessex. Hardy was born a bookworn and in Jude the boy was crazy about books. Whon Hardy was a young boy a Ioeal youngster driving a baker's eart had stopped him and wanted to borrow Indy's Latin gremar. In tho novel Jude Fawley asked for sorae gramax and 2 la drove a baker's cart for his great-aunt. When Hardy was older he taught himelti Horew Just as did Jude. These and many other ingtances point out the similarities botween Jude Fawley and

931bide. p. 141 . 
Thomas Hardy'

Jude bivelf had com from a lower alass background but was confrontad with reprosentatives of tho uppoy class in the form of olergymon. Wost of the clorgy were form of local gentry and were frequently Iandownors. They cano in contact wh the lower class poasants in the process of their religious dutles but also beause they played the rolo of the squirarchy towaris the Iabouring class. Tho Angliean parsons were congidered mambers of the local gentry. "lise tho person onjoyed a confortable and leisured gentility. second only to that of the squire In the parish." 95

AIthough the alexgy, according to Colquhoun's table, were part of the upper class, they wero divided within the social category. "The Elshops, the Cathedral clergy and wealthier parish priests were part of the "onjoylng"elass;"96 the remainder were lesser gentry. The upper class clergy Hendy was familiar whth eonstitutod both the looal centw and a few representatives of the higher clergy, if the term may be used. Thoms Hardy oriticized the clergy for the injustices comitted against the lower classes. The offenses were prinarily in the field of education: Hardy felt that only the privileged vere able to aequire a good aducation when the cloxics were in charge of the whole educational systam.

The evelopsent of publio odueation das difleult to achieve. Long before the 1840's, Whitbread in 1806 . Broughan in 1820, and Roobuek in 1833 had brought forutar bills for ereating a rato-ajded systen of

94wober, ap. e1t, p. 201. 15ingfield-Stratrond, op. elt., p* 193. 96 trovelyan, ag. cit., p. 45. 
oducation. The maxch of intallect, they belleved, needed a nationaly enforoed discipline, and the state would have to supplement the work of the two main roluntary odncetional sootetios-tho British and Foreign Schoel Soeiety (founded in 180\%) whioh included both Churchmen and Nonoonformsts, and the National. Societsy (founcted In 1812) which was oxclusivelyt Church of England 97

Efforts to establish a national systom of eduestion were tharted due to the relfigious zeal of the sponsors of the voluntary soejotites. There wo a clash between Anglican demands for complete control and Honconforat anphasis on religious liberty.

Thoma Hardy's conoem about oducation in England fits in quite closely with his coneem about the rigia class sytam in British socioty. He felt that restricting odueation to the tehosen" was but another fora of class division and stratifleation with excluation of the lower classes. The novel Jude the Obgeure was tho instrument Hardy used to express his fooling against the Church and its control over the British oducational systom.

During the eighteenth century the primary edroation of the poor had been left to the zeal of roluntary workers, prompted by religinus, charitable, and other motives, A Large proportion of the popriation was entirely without the mans of aducation nd this area was not considered a duty of tho state. What edueation was available cane through religious channels. There was wuch disagrenent between the Itstablishod chureh and various Dissenter groups for neither accepted the manner in which 97 Ass Briggs, op. g1te, p. 336. 
their children were receiving religious-educational instmaction.

Around the turn of the century the Britist governont recognized the need to talke some investigative stops in order to rectify the sit.m uation.
In 1816 Broushan ' Coundssion set to inquire into the state of the sducation of tho lower ondors in london, but the evldence taken coneumed chienly the abnso of cheriteible endomments. In 1818 its incuiry vas made to oxtend to the whol country, and it continued to sit for nary yous. There wore shown to be 19.326 infant and day schools of all kinds, attended by 605.704 pupils of all classes; whereas it was astinated that the number of children requinting elewentary teaching was over two mil7tins. To remedy the defect 2 we supply Brougham brought fownand a B11 in 1820, in which he proposed a Iocal rate, placine Iocal control in the hands of the matrates .... The Bill was rejeated. 98

Sinoe no solution could be found to the question of edueation and the state. the clergy continued to adritnister the schools of the nation. The Fonster Education Act was not passad unt11 1870 and it was not a complete solution for it dia not deal directly with the injustiees of education at the universfty Iovel. As late as 1870 Thomas Hardy stij]. sew signs of inequelitios in the soclal system in the fleld of education. It was for this reason that he penned Jude the Obscure. The notol was his last attempt to awaken the reading public and force thom to become aware of the fact that olasses did still oxist and that those elasses wors essentially no different than the separat upper and lower olases he had known as a boy in tossex.

Conditions at Oxford and Cantoridge were so strict and uncompromising 96 Traill, op. cit. P. 831 . 
that it was virtudily imposstble for aryone other than the wealthy aristocrats and thesir sous to go thers. Abinity in any other then the upper oluss wa ignomed.

At the beginning of the nineteenth contury the excellence of a student's merits were tosted at Cambridge only in one way, by the thematieal Trivos ... At oxford there had been no exemination for degrees until the beginning of the eontury, whon elsssical and mathomatical honours $11 \mathrm{sts}$ begen. Unt11 1850 no other redieal chang was offected at oither undversity. 99

Throughout the ninetionth contury the number of porsons admittod to the unfversitios was extremely amell. Cambridgo had reluotantly admitted additional students but the inorease was not proportionate to the growth of the population In England at this time. Jude the Obseive opened up the socio-economic problems of British education in the nineteenth contury. Jude Fuwley made an attempt to breach the gap which oxd sted between his lower olass agricultural bockground and the upper elass world of the acadeny. Handy 13 lustrated the class confliets in Jude through Jude hinself, his farm wife Arabella, and Phillotson. In Jude the Obseure it is somewhat difficult to ssign ary mojor oharacter to the uppor class because there is no specifio individual who exactly fits the role. The most likely charaoter would bo Mr. Filllotson, who, at the boginning of the novel left the agrioultural communtty and went to the eity in sareh of a university degree. Wr. Phtllotson's intention was to solidify his idontifieation with the olorieal 99 ibid., p. 846. 
mpper olass, those individuals who controlled the world of the academies,

Thare ro contacts and rosulting confliets between both the lower and uppen classes. Whe prinary struggle in the novel exists between Jude and the upper alass in the acadenize world. Since the olergy and the scholars of oxford and Cambridge were often one and tho same. Jude was in a clash whin both the Churoh and tho whole fleld of aducation. Jude Tarloy originated from a remoto, rural comer of England.

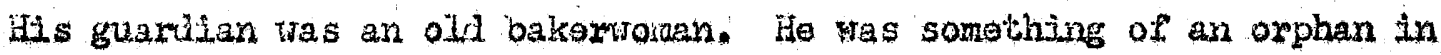
the worla sineo Hardy describes his parents as both dead. Jude's groataunt desoribod hin thus:

He came from Mellstook, down in South Wossox ... where his father was living, and was took wi' the shakings fow death. and died in twe daye .... It would ha' been a blessing if Goddy mighty had took theo too, wh' thy mother and father, poor useless boy " 100

Whoughout the novel Jude's Iower class background and rustio heritage prevented him from ever broaking down the walls whioh divided the elasses. Aftar a disastrous contact with the uppor eless at Christminster /4ady's name for an institution similar to oxford or Cambridie]. Hardy described Jude as:
*.. oddly swathed, palo as a momunental figure in alabaster, and moh stared at by othow passengers. ... On his face showed the determined purpose that alone custained him, but to which his weakness afforderl a sorry foundation. 101

Not unlike Tess, Jade had lost everything once ho eare in contact with

100 Hardy. Jude the Obsoure (Hew Iork, 1961), D. 17.

101 1bid:. p. 382 . 
rembers of the upper dass. As late as 1396 whon Jude was witten and publishod, Mardy still felt that any contact botwoen the classes tould result in the downely. of the simple labourers. In the case of Jude. this prover to be tmie.

Jude had been wamed by his fellow v117agers not to attempt to enter the rorld of the upper class but he was Intont on doing so regardless. His greatmant sald about chosintminster. HIt is a place moh too good for gro aver to have much to do wth ..." 102 She continued by remarking, "We'vo never had anything to do with folk in Christrinster, now folk in Chrtstrinster with us." I03 Stuch commonts reflect the conception whych comon people held about a location reserved for the upper elass. Unaware of the fate which awajted him there, Jude coitunued to think of Christminster as "the hevenly Jerusalom."104

Hardy stressed over and over agein in Jude the obscure that the town of Chrostminster was reserved for the upper elass. When Jude Hawley asked a neighbor man about the place, the man corwarned bim:

Ah, young man, you ld bave to got your head screwed on t'other way before you conld read what thay raad there. Tis all leaming there-nothing but loaming. axcept religion. And that's Iearning, too, for $I$ never could understand it. Yos, itis a serlousminded placs. 105

Haxdy very elearly expressed his ow feelings through the Iips of a

102

Lbld. p. 22.

$103_{1012}$

104 ibid.. 9. 24.

${ }^{105}$ Hardy, Jude, P. 28. 
local vitlager. Class disorinination vas a very obvious part of the Forld of aductizon which tra reserved for the upper class. There was no place in the wopar olsss world for a lowor elase labourer who aspired to nore. Jude hinself roalized that he wes reaching for the irapossiblo but he tritgd to break down the barrier between the clisses axyray. The result wes his ow dowrall. Hardy again denonstrated that when the Iower alass mustios come in contact wint the upper clesta uristocrats, the loter clnsses nill be made to suffer as a result of the relationship. once Jud had expextenced personal catastrophe due to his fallure to obtairi the goal ho set for himbelf, he despairs and wituratoly brings about his on destmation. Ife pessimistically thiniks to hineelf:

They seen laughing at mel the phentoms all about here, In the college axchways, and windows. They used to look friendly in the old days, perticularity Addison, and Glbbon, and Johnson, and Dr. Browne, and Blihop Ken -106

A second and porhaps clearer exmple of the lower class rustic in Jude the obsoure appeared In the character of Arabella.

She was a fine dark-eyed girl, not exacty liand sorne, but capable of pessing as such at a Ilttle distance, despito some ooarsenoss of skin and fjore. She had a round and prominent bowom. finl] 1ips, perfect teoth, and the rtoh complextion of a Cochin hen's ogs, She vas a comploto and substantial anina?

107

How father was a farmer and a locel pig-breeder. Arabolla hefself worked 106 1 bid, p. 387 .

107 Bardy, Jude, p. 43. 
to help her parents in their business by eleaning the innards of pigs. Most of her friends and associates orlginated from the samo background as did sho. The young woman wh thom she worked shared local gesspl and took part in the sane dally activitles as Arabolla. Hardy portrays hor as a typical, rather exude, daughter of the agricultural world of Wessex. When she and Jude married, she kept him at the same soctal level as herself. She squelohed Jude's aspirations and mantained their lovol of IIving as it had always been - that of the comon labourer or famer. The only PIgure in Jude the Obsoure who elearly resembled the upper elass was Mr. Phillotson. 108 He was a I00al sohoolnaster who loft Milstock to seok a career in Christminster. Jude followed in his footstops.

Phillotson, Iike Angel clare, was in Hardy's mind an ambivalent character. He was eaught at the crossroads of the two classes, upper and lower. He knew the value that ansversity degree would have for hin if he was to be suocessful. A degree wa required if he was to be a momber of the upper aless. "It is the necessary hallmark of a man who wants to do anything ..." he told Jude " 109 His drean was to be a man of the univeratty, aniversity graduate and then be ordained. Unfortunatoly. Phillotson did not ouceod in achloving his goal. Whon Jude eame to Christininster he sought out He. Phillotson, expecting to find him in a postution of high importanes, Ho was informed, however, that PhIllotson was a vilage schoolmater and no more. "Thon ho couldn't do 1ti" Jude remarked.

${ }^{108}$ Jude also oam in contest with the deans of the univeresty but only by all. They represented the elite of the upper elass but his relationshtp to thom we distant.

${ }^{109}$ Hemiy. Jude, p. 14. 
In Jude the Obseure Phillotsan could be said to have beon a aymbol of a figure who stood for all, that was of the npper class in university 1ife. In actuality there was no spectfie individual in the novel with whom Jude eame in contuct who twuly ropresontod the olerioal facet of the upper elass. No one opectele individual ame in contact with Jude to 117ustrate the conflet which extsted botween his goal to onter the upper elase universty Iifo and the aristocratic world of Chriotminster. Platlotaon is the elosest example in the ontire novel. for he left the agrieultural community and at least made an attempt to otay. In and around the acadonie 11 fo.

One might say in Jude thit the concept of class stratifleation and alas connict brought about by such stratifleation was not cloarly oxplained in the novel, apoeifleeliy bearse there was no one Individual character to ropresent the uppor elass, Desplte the fact that Phillotwon falled to reach his goll and therefore we perhaps fonovor just as mueh member of the lowrex class as wes Jude himale, one of the mor themes of Jude ws one of elass p1tted against elass. Instead of arguing his polnt of view using spectic charaters to wepresent the upper and 1ower alass, Handy drew a vivid pleture of the life of the Iower elass Iabourers and wrote the entire nowl as a story of the upper alass in contrast to the cokmon man. It was a pletaxe of one man, Jude. ageinat the whole world, wo to apolk. Handy's jude explained hor the aspirations of a labouring youth could nover be fulfilied as long as there wes a barmer between the soctal elasses. Jude stood for all young people 110 in England who wero boing dented progreaston in the world due 110.1b1d.. 103. 
to the unfair pressures put upon them by the upper class. The upper class was aotuilly preventing progress in nodem England. This, thought Hardy, was a sertous defect in the social structure of his native land.

Only a wall divided him LJude] from those.... mon who had nothing to do from moming till night but to read, maxk, loaxn, and 1mwardly digest. Only a wall--but what a wall t

111

The wall was built of prejudies and elass hatred. The wall in Jude was a symbol of the barrior which stood botweon the uppor and lower classes. It soemed unusual to many of Handy's roadors that he should attempt to be a centemporary sodial oritie bocause his storios wore, as they percelved thom, fifty years behind times, Hardy used a pre-industrial sotting for Tess and jude to 1llustrate the grievanees he had against soeitety that was deop in the middle of the machine age. Howover, It is important to noto that the same siturition oxdstod in proIndustrial England as In modorn Industrial British society. Hardy folt that his contomporarios had forgotten that social ixbalances still oxtstod, He mado his issues very elear to the reading public by plecing his oharecters in an agrieultural. pro-industrialized onvironment whore soeial disparitios wore more elearly exposed to the naked oyc. A socond aspect of Hardy's social oritiel sam pertainod to oconomio conditions in England. Not only did Hardy write in mannor whioh compared an eaplior agrieultiural age with lator induatrialized poriod of time, but he actwelly foresaw dangers threatening Brittioh agrieultural Iffo once gain. When he was thirty-five, Thomas Hardy saw all

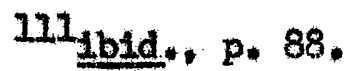


about hin the signs of another agrioultural deprosslon. W1th that depression ho feared would com the samo soelal and oonomic disease he had experloneed in his youth in Wessex. Agricultural workers would face jears of famine; the upper eless landowners would again profit. He forean the pitting of elass againgt oless whon the comon man would once again be made to suffer at the hands of the upper class.

Thomes Handy saw a soolal malady in the present and future of Fngland and tried to make his roading publie aware of the danger. His public rejected him. He was able to approach the comonest aspects of Iffe In such a mannor as to lay bare its roal signifieance in general sohene of things, and to present an appaxentiy trivial situation in such a way as to make 1 t the vahiole for the commuleation of an wltimato trath 12

To many, however, the truth was diffleult to acept so it was rejected and discanded. The now upper olass - the wealthy Induatrial middle class-- refused to look at the world about them in reallstie tewne and as a regult closed their gos and deafoned their ars to goaial oritlos. Exeuges wore mude and Tess and Jude were objected to on moral

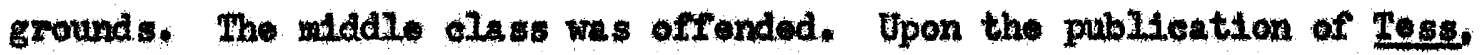
the pablic could talk of nothing alse but the othioul and moral armpathy Hardy gave to an unwed mother. The publio did not see thet her story was a plea for simple charlty and at the same tine was a bitter sttaok against Vietorian soolal hypoorlsy. Jude wa Ilkenliso attacked. by the publle becuse hardy oried out for a realistle appromeh to the 112 Ernest Brennecke, Thome Hardy's Universe (New Xork, 1966), p. 13. 
problem of divores. The moral values of the Vletorians had boen attacked and thoir pride offended; the public looked no furthor into Hardy's novels to see the deeper moaning. H1s 1 ssues about class diviston and conflict wore ignored, overshadowed by Vletorian hypoerlsy.

If it 1s tmie that an age is reflected in 1 ts 11 terature, then Tess and Jude were truly representative of the Vietortan age. Historians of the present and of the ruture ean look beck and see not only that Thomas Handy was a social orttic who made clear the class consciousness in British soejety but also that his Vietorian contemporaries were wyperites who hoard him not. Handy never wrote another novel. 


\section{BIBLIOGRAPHY}

Aborarombie, Lasoelles, Thomas Hardy, a Critical Study. Loxion: Mertin Soeker, 1912.

Arnstain, Waltor L. Britain Testerday and Today. Boston: D. C. Hath \& Co, 1966.

Ausubel, Herman. The Late Vlotoriens. Now Toxk: D. Van Iostrand Co.. Ine.. 1955.

Batho, Edith C, and Bonany Dobree. Tho Vlatorians and After. New York: Dover Fublications. Ine. 1950.

Bromnecke, Jr.. Exnest. The Itfe of Thomas Hardy. Now Yorki Greonberg Publieations, Ine., 1925.

New York: Russe11 \& Russell, 1966.

Briggs, Asa. The Making of Modern Fingland. Hew Tork: Harper Row, 1959.

Briggs, Mitton and Porey Jordan. Eeonomis History of England. London, Untwersity Tutorial Press Itd.. 1949.

Buakley, Jerome Hamilton. The Vetorian Temper. Cambridge : Hervard University Press, 1951.

Bum, W. L. The Age of Equipotige. Now York $\mathrm{W}, W$, Norton \& Co, Ins., 1964 .

Ceeil. David. Handr the Novelist. Ionden. Constable \& Co.. Ine., 1943.

Chew, Samuel C. Thomes Hardy, Poet and Novell st. New York and Iondon: Longmans, Green and Co., 1921.

Cole, G. D. H. and Raymond Postgato. The Britlsh Conmon Poople. Iondon: Mathuen, 1961.

Cole, G. D. H. Studtes in cleas Strueture. Iondon: Routlodge \& Pavl Kegan, 1955.

Dahrendorf, Rolf. Class and Class Confliet in Industrial Sooloty. Stanford: Stanford University Pross, 1959.

Evans, R. J. The Vietorian Age. Iondon: Edwand Arrold \& Co. 1950. 
Guerard, Albext J. Thomas Hardy. Cambridge: Harvard University Press, 1949.

Halovy. Elie. A History of the English People in the Nineteenth Conturv. "The Ifbersi Awakening, 1815-1830."

Now York: Bames \& Noble. 1961.

$-m-m-m-m$

"Viotorian Toars, 1841-1895."

Iondont Ermest Bem Ltd.. 1951.

Hammond, J. I, and Barbara. The Age of the Chartists, 1832-1854.

Now York and London: Longmans, Green and Co.. 1930.

Hardy, Evelyn. Thomas Handv, a Critleal Blogrephy.

New Iork: St. Martin's Press, 1954.

Hardy, Floxonee Emily, The life of Thomas Hardy.

New Tork: St. Martin's Pross, 1962.

Hardy, Thems, Jude the Obsoure.

Now Ioxks The How Amorieen Llbraty, 1961.

- Tess of the dUrberid11es.

Now Iowk; The Now Amorienn Library, 1964.

Harrison, J. F. C., od. Sooloty and Pollties In England 1780-1960.

Now York: Haxpex \& Row, 1965 .

Hearnshaw, F. J. C. The Soclal and Politioal Ideas of Some

Representative Thinkers of the Vetorian Are.

Now York: Barnes \& Noble. Ine., 1950.

Heaton, Herbert. Feonomic Histom of Europe.

Now York, Haper \& Row, 1948.

Holloway, John. The Vlotortan Sage.

Iondon: Menslian \& Co. Itd., 1953.

Houghton, Walter E. The VLetorian Brame of Mind. London: Yale University Press, 2957.

Kitson-Clark, 0. The Malating of VLetorlen England.

Cambridge, Harvard University Press, 1962.

Iew1. Roy and Angus Made. The English Middle Classos.

Now York: Knopr, 1950 . 
Martin, Everett Dean. The Confliet of the Industrial and the Mass In the Modern Worla. Now Tork: Honry Holt \& Co. 1932.

Mtehe11, R. J. and M. D. R. Ioys. A Htotory of the Engl1sh Poople. Now York London: Iongmans, Green and Co., 1950.

Potrie, Sir Charles. The Viotorians. Now Xork: David Nickay, 1961.

Putland, William R. Thoms Hardy, A Study of his Writings and thier Becksround. Hew York: RusselI \& Russell, Ine., 1962.

Tra111. H. D. and J.S. Marm. Soolal England (Vol. VI). Londoni Cassell \& Co. Itd.. 1904.

Trevelyan, Geong Macalay. Illustrated English Soc1al H1 story. Landon and New York! Iongmans, Green and Co., 1949-52.

Wober, Carl J. Handy of Wessox. Hamdon, Conn. A Archon Books, 1962.

Webster, Harvey Curtis. On A Daxkling Plain. Chie gol The Untversity of Chlengo Press, 1947.

W111lams, Raymond. Gulture and Soctety, 1780-1950. New Iork, Columbia University Press, 1958.

Wingeleld-Stratford, Esme. The Vlatorian Crelo. Now York: William Murrow \& Co., 1935. 